\title{
CrimRxiv
}

\section{Video Games, Crime and Next-Gen Deviance: Reorienting the Debate}

Craig Kelly, Adam Lynes, Kevin Hoffin

Published on: Jul 03, 2020

DOI: $10.21428 / c b 6 a b 371.23221 a 2 a$

License: Creative Commons Attribution 4.0 International License (CC-BY 4.0). 
